\title{
Directive and Commissive Speech Acts in "Kartini" Movie
}

\author{
Ririn Nurul Azizah* \\ Indonesian Language and Literature Education of \\ Graduate School \\ Universitas Negeri Yogyakarta \\ Yogyakarta, Indonesia \\ ririnnurul.2018@student.uny.ac.id
}

\author{
Suhardi \\ Faculty of Language and Art \\ Universitas Negeri Yogyakarta \\ Yogyakarta, Indonesia \\ suhardi@uny.ac.id
}

\begin{abstract}
The aim of this research is to describe the directive and commisive speech act found in Kartini movie. This is a descriptive qualitative research. The data collection was carried out by observing attentively speeches in Kartini movie in relation to directive and commisive speech act. This research uses Ibrahim's theory which suggests six forms of directive speech action: requesting, questioning, commanding, prohibiting, giving permission, and giving advice and two forms of commissive speech act: promise and offer. The result of the study shows that the speeches in Kartini movie has 1) five forms of directive speech action that include requesting, questioning, commanding, prohibiting and giving advice, and 2) two forms of commissive speech action that include promise and offer.
\end{abstract}

Keywords: directive, commissive, Kartini movie

\section{INTRODUCTION}

Language plays a very important role in human interaction since the main function of language is to communicate (Ayeomoni \& Akinkuolere, 2012: 461-468). The communicative function of language makes it possible for people to interact one another. Several communicative functions of language are expressing agreement, disagreement, and thanking (Purwo, 1990: 2). Language as a means of communication is used to convey ideas, both in the form of written or spoken language. Written language is a language which is written in a media, while the spoken language is the one spoken through aspeech. A process of communication, especially the spoken one, consists of two parts, namely speech event and speech act. Speech events are a series of several speech acts that are organized. Speech events may refer to the purpose of the event, while speech acts refer to the speech intention (Chaer dan Agustina, 2010: 50).

Speech act is both speech and action. It is an expression that acts something (Rustono, 1999: 32). Similarly, Ibrahim (1993: 109) said that speech acts include expressions of psychological situations, such as thanking and apologizing, and social speech acts such as influencing the behavior of others, like reminding and commanding, or making contracts, as promising, and naming. Not only in real life situation, in everyday life speeches can be found in literatures such as film, play, and comics. Film is a kind of literature that illustrates a story exhibited by actors. Film can be a mean for conveying ideas, messages, thoughts, and feelings that want to be revealed to the public (Supriyati dan Tarmini, 2014: 62-77). Film, which is often called as movie, is an embodiment of life.

This study examines the speeches, specifically the speech acts, in the movie entitled Kartini directed by Hanung Bramantyo. The theory of speech acts was first introduced by Austin (1962) in his book entitled "How to Do Things with Words". It is explained in the book that speech activity does not only involve saying something but also doing something. Austin divided speech acts into three categories, 1) locutionary act, 2) illocutionary act, and 3) perlocutionary act (Supriyati dan Tarmini, 2014: 62-77). Locutionary act is a proposition act, placed on the level of saying something. This action results in words spoken by the speaker. Illocutionary act is the action of doing something. It refers to what action is done by the speaker when an utterance is spoken. Therefore, it is the essence of speech act. Perlocutionary act is the effect of the utterance on the interlocutor's feeling, thought, or action, such as inspiring or entertaining (Ayeomoni \& Akinkuolere, 2012: 461-468).

Illocutionary acts are divided into five categories; assertive, directive, commissive, expressive, and declarative (Leech, 1993: 164). Assertive is a speech where the speaker commits for the truth of a proposition. Directive is a speech where the speaker commands the interlocutor to do something. Commissive is a speech where the speaker acts for future action, such as promising or offering. Expressive is a speech where the speaker makes his/ her action acknowledged by the interlocutor, such as blaming and apologizing. Declarative is a speech where the speech itself brings a correspondence between the speech proposition's context and reality, such as baptizing and firing (Bilbow, 2002: 287). The speeches in this movie attracted the author to conduct a study on this field since it is a way to express thoughts and feelings experienced through spoken speech. However, in this study, the author focuses only on directive and commissive speeches because preliminary observation revealed that directive and commissive speeches are two categories mostly found in the movie.

The first area investigated in this study is the forms of directive and commissive speech act employed by the characters in that movie. Ibrahim (1993: 28) divides the form of directive speech act into six categories: requesting, asking question, command, prohibition, giving permission, 
and advice. Meanwhile, commissive speech act is divided into two: promise and offer. Each form of directive and commissive has its own function. For example, asking form in commissive speech act functions to ask question, dictate, prohibit, or suggest, while promise form in commissive speech act functions to make a promise or give an offering.

Since speech may contain certain pragmatic intentions, analyzing speech acts should also consider the context. The context of speech is situations surrounding the speech, such location, time, media, and conditions (Sudaryat, 2009: 143). Therefore, the uniqueness of language which can be both verbal expression and action attract the author to conduct a study on this field, especially the forms and functions of directive and commissive speech acts in Kartini movie directed by Hanung Bramantyo.

\section{METHOD}

This was a descriptive qualitative research. The data collected were in the form of words or images, not numbers (Sugiyono, 2012: 22). They were directive and commissive speeches found in Kartini movie. The data source of this research was a movie entitled Kartini. The data of this research were the speeches made by the actors in the movie. They were 1) Kartini, 2) Kardinah, 3) Roekmini, 4) Kartono, 5) Ngasirah, 6) RA Moeryam, 7) Mr. Sosroadiningrat, 8) Mr. Ovink-Soer, 9) Ny. Ovink-Soer, 10) RM Joyoadiningrat, 11) RM Adipati Ario Sosroningrat, 12) Slamet, 13) Busono, 14) Pak Atmo, 15) Hadiningrat, and some other characters.

The data collection in this research was carried out by using non-participant observation and note taking techniques. In non-participant observation, the researcher was not directly involved in participating and determining the formation and appearance of prospective data except only as observer (Sudaryanto, 2015: 204). The researcher listened to the use of speech acts spoken by the speakers (actors). Meanwhile, the note taking technique was employed by transcribing speech or dialogue from the movie. After completing the transcription, the data were then classified in data card.

The instruments used in this research were indicator tables, data cards, and data transcript sheets. The validity of the data in this study was gained by re-reading technique. By using this technique, the researcher re-read the data to increase its accuracy and match it to the theory used to increase the level of data trustworthiness. The data in this study were analyzed by using pragmatic matching method. First, the researcher collected the data, recorded, and classified the data according to the form and function of directive and commissive speech acts by considering the context of speech. There were three steps in analyzing the qualitative data; data reduction, data display, and conclusion drawing or verification. Data reduction was done by summarizing, choosing the main points, and focusing on the important aspects. Data display (data presentation) was served in the form of brief descriptions (narrative) and charts and making correlations between categories. Conclusion drawing or verification was the last step where the author wrapped up the results of the study.

\section{RESEARCH FINDINGS}

The main characters in the movie are Kartini, Kardinah, Roekmini, Kartono, Ngasirah, RA Moeryam, Tuan Sosroningrat, Slamet, Busono, Pak Atmo, and Hadiningrat. The speech spoken by the characters in Kartini movie when they are having conversation is not merely a language expression. Some of them may contain action addressed to the interlocutor. This is what is called speech act. Speech act is realized into several forms and each form carries function. The function intended by speakers when uttering a speech act refers to illocutionary speech act. There are several categories of illocutionary act, but this study focuses on the directive and commissive act.

The results of the study show that there are five forms of directive speech act employed by the characters in Kartini movie. They are request, command, prohibition, advice. Meanwhile, two kinds of commissive speech act found in this study are promise and offer. The following section discussed those findings in detail.

\section{Directive Speech \\ Requesting}

Asking is a speech act uttered by someone who wants her interlocutor to do something for him/her. Below is an example of request in Kartini movie.

Context : It happens when there is a recitation held at Tuan Sosroningrat's house. Before the recitation begins, Tuan Sosroningrat has unexpected guests, that is Dimas Aryo and his family. One of them is Haryono, his son. The guest come for a plan to marry Kardinah with Haryono, the vice regent of Pemalang. Tuan Sosroningrat has already promised them about his marriage in the past. When the recitation is still going on, Kardinah feels uneasy since she worries about Haryono.

\section{Kardinah : "Ni, ayo di kamar saja. Perasaanku tidak enak". \\ Kartini : "Tunggu sebentar. Aku ini belum pernah mendengarkan pengajian seperti ini”.}

The speech made by Kardinah aims to ask Kartini to go into her room. That speech is a form of request. Here she says, "Let's go into the room." By using the word let, it is seen that it is a kind of asking. For Kartini, the effect brought by the request spoken by Kartini is that she needs to do the action of going with Kardilah to Kardilah's room. 


\section{Questioning}

Asking for information is a form of speech act that is usually uttered because of the speaker's curiosity. An example of data showing this function in Kartini movie is shown below.

Context : This dialogue occurs when there is an Islamic lecture led by a Kyai coming from different district. After having the lecture, Kartini feels interested to his lecture and repeatedly asks to her aunt about who the Kyai is.

\section{Kartini : "Bulik, siapa kyai itu?". \\ Bulik : "Itu kyai Soleh. Paklik kamu yang mengajak beliau untuk mengisi pengajian ini. Kenapa?".}

The speech uttered by Kartini in this dialogue is meant to ask for information on who the Kyai is to her aunt. For the interlocutor, the speech act "Bulik, who is the kyai?" brings an effect that she needs to answer the question by giving the information needed.

\section{Commanding}

Command is a form of speech act that is usually uttered since the speaker wants the interlocutor to do something for her. It is almost same as requesting, but command has stronger effect since it is usually spoken by those who are higher in position to the lower one, like teacher to the student or boss to the employee. An example of command found in the movie is shown below.

Context : This conversation occurs in a house hall. Kartini mentions all conditions so that she can accept the proposal from the Regent of Rembang, RM. Joyoadiningrat. The characters involved in the conversation are Kartini, Tuan Sosroningrat, RA Moeryam, Slamet, and Busono. RA Moeryam rejects all conditions told by Kartini. Then, suddenly Lastri (Kartini's old sister) comes in to pick her child and takes all her child's belongings. Lastri has been divorced by her husband. She extremely supports all requirements that is mentioned by Kartini. Finally, Tuan Sosroningrat commands Kartini to write all those requirements.

$$
\begin{aligned}
\text { Tuan Sosroningrat : " } & \text { Baiklah jika begitu } \\
& \text { cepat-cepat segera } \\
& \text { dituliskan syarat-syarat } \\
& \text { tersebut. Lalu, } \\
& \text { dikirimkan ke Bupati } \\
& \text { Rembang". }
\end{aligned}
$$

The speech spoken by Tuan Sosroningrat to Kartini in this dialogue is meant to command her to write the requirements she just mentioned on a piece of letter and send the paper to the Regent of Rembang. The command is seen clearly when he said "OK. now write all those requirements immediately...". For the interlocutor, the speech act brings an effect to do what he commands her to do, that is writing all the requirements she just mentions.

\section{Prohibiting}

Prohibition is a speech act functions to not allow someone to do something. A data containing this function is shown below.

Context : Kartini wants to beg a craftsman to made her a leather puppet but the craftsman refuses Kartini's command. Here, Kartini's father interferes the conversation to make Kartini's wish accomplished. But then, Busono prohibits or prevents his father not to be involved in the business.

$$
\begin{array}{ll}
\text { Ayah } & : \text { "Ini urusanku". } \\
\text { Busono } & : \text { "Jangan, Ayah". } \\
\text { Ayah } & : \text { "Tidak usah ikut campur". }
\end{array}
$$

The speech spoken by Busono to his father is a kind of prohibition on being involved in Kartini's business. By saying "No, Dad!", he does not agree to what his father just says that commanding the craftsman to do as what Kartini ask him to do is his business. For the interlocutor (the father), that speech brings an effect not to do what he really wants to do.

\section{Suggesting}

Suggesting is a kind of advice where the speaker does not impose the idea he proposes; he only gives possible plan or action that can be considered by the interlocutor. Sometimes this speech act may also show sympathy. An example of suggesting found in Kartini movie is shown below.

Context : This utterance occurs when Tuan Bupati falls fainted in his room. RA Moeryam who looks at him in panic immediately asks Pak Atmo to call a doctor. After examining the patient, the doctor gives a suggestion to Tuan Bupati's family.

Dokter : "Maaf, saya harus memberi tahu Anda bahwa Tuan Bupati karena ada pendarahan di dalam otaknya. Sebaiknya beliau jangan dibebani pikiran berat."

This speech is spoken by the doctor to Tuan Bupati's family. He told them that Tuan Bupati has a problem with his brain and the suggestion given by the doctor was "He shouldn't be burdened with serious thought." Here, the speaker suggests the family to treat him well since serious thought may worsen his health problem. It is a directive speech act formed in an advice whose function is suggesting. 


\section{Commissive Speech Promising}

Promising is a speech act telling the interlocutor that the speaker will certainly do something in the future. The following data shows an example promising function found in Kartini movie.

Context : There are two persons involved in the dialogue: Menir and Tuan Sosroningrat. Menir says that all Kartini's papers and literary works will be shown in Den Haag in Queen Wilhemina's coronation. Tuan Sosroningrat says that by doing so, Menir will get a name.

$\begin{aligned} \text { Menir } \quad \text { : "Saya butuh sekali Kartini. Saya } & \text { butuh sekali. Dan kemudian saya } \\ & \text { akan berikan yang dibutuhkan } \\ & \text { untuk masa depan Slamet dan } \\ & \text { Busono. }\end{aligned}$

The speech spoken by Menir contains promising function. He tells the interlocutor that in the future he will certainly do what he says. It is seen in the second sentence "And then I will give what is needed for Slamet and Busono's future.". Within this function, it is seen that the speech is actually addressed to the speaker himself to do what is just said.

\section{Offering}

Offering is form of speech act where a speaker proposes several options for doing a negotiation with the interlocutor. An example of data with offering function found in Kartini movie is shown below.

Context : Kartini will get married with R.M Joyoadiiningrat. She will accept his mariage proposal if several requirements are fulfilled. However, her stepmother, R.A Moeryam disagrees with all the requirements proposed by Kartini.

\section{Kartini : : "Yang pertama, saya tidak mau mencuci kaki R. M. \\ Joyoadiningrat di pelaminan. Syarat yang kedua ....”.}

The speech is uttered by Kartini to some of her family members. By saying "First, I don't want to wash R.M. Joyoadiningrat's feet in the wedding. The second condition ...", the speaker gives some offers to herself to accept his mariage proposal. It is a kind of commissive speech act formed in an offer. By mentioning several requirements before accepting R.M. Joyoadiningrat's proposal, Kartini wants to show that she has dignity as a woman. She thinks that all men and women are equal. Thus, for Kartini, washing the husband's feet as one of Javanese rituals on a wedding day is a symbol of women's inferiority in marital life.

\section{CONCLUSION}

Based on the discussion above, it is found that both directive and commissive speech acts occur in Kartini movie. Some functions of directive speech act found in the movie are commanding and suggesting. Meanwhile, in terms of commissive speech act, the study found promising and offering functions. Based on the data analysis, it is revealed that requesting, questioning, commanding are the most prominent data found in the dialogues of Kartini movie. The prominence of those three categories is due to the possibility of the characters to express their thoughts and feelings by using those forms. The characters in Kartini movie can take advantage of speech act to do something that they want.

\section{REFERENCES}

Ayeomoni, Omoniyi Moses and Akinkuolere, Olajoke Susan. (2012). A pragmatic analysis of victory and inaugural speeches of president Umaru Musa Yar'adua. Academy Publisher Manufactured in Finland, 2, 461-468.

Bilbow, Grahame T. (2002). Commissive speech act use in intercultural business meetings. International Review of Applied Linguistics in Language Teaching, 40, 287.

Chaer, Abdul and Agustina, Leonie. (2010). Sociolinguistics: initial introduction. Jakarta: Rineka Cipta.

Ibrahim, Abdul Syukur. (1993). Speech act review. Surabaya: National Business.

Leech, Geoffrey. (1993). The Principles of Pragmatics. (Translation of Oka, M.D.D. \& Setyadi Setyapranata). Jakarta: Universitas Indonesia Press. (Original book published in 1983)

Purwo, Bambang Kaswanti. (1990). Pragmatics and language teaching. Yogyakarta: Canisius.

Rustono. (1999). Pragmatic points. Semarang: CV. IKIP Semarang Press.

Sudaryanto. (2015). Methods and various techniques of language analysis. Yogyakarta: Duta Wacana University Press.

Sudaryat, Yayat. (2009). Meaning in discourse (Principles of semantics and pragmatics. Bandung: CV Yrama Widya.

Sugiyono (2012). Educational research methods (quantitative, qualitative, and $\mathrm{R} \& \mathrm{D}$ approaches). Bandung: Alfabeta.

Supriyati and Tarmini, Wiini. (2014). Speech acts reign in the film of the Rainbow Warriors and their implications for learning Indonesian in junior high school. Journal of Paedagogia, 17, 62-77.

(2017). Kartini. Accessed from the web https://en.wikipedia.org on November 10, 2018 at 12:25 WIB. 